\title{
Mukositis Oral dan Kualitas Hidup Spesifik-Mukositis Oral pada Anak Kanker yang Menjalani Kemoterapi
}

\author{
Dwi Novrianda ${ }^{a}$, Yulastri Arif ${ }^{b}$ \\ ${ }^{a}$ Bagian Keperawatan Maternitas-Anak, Fakultas Keperawatan Universitas Andalas Padang \\ ${ }^{\mathrm{b}}$ Bagian Dasar Keperawatan dan Keperawatan Dasar, Fakultas Keperawatan Universitas \\ Andalas Padang
}

\begin{abstract}
One of the side effects generally occur during chemotherapy is oral mucositis. Disorders due to oral mucositis often affects the psychological and decreased quality of life of children. Therefore, It is important to determine the relationship of oral mucositis in cancer patients undergoing chemotherapy and quality of life related to oral mucositis. This research was descriptive analytic with cross sectional approach. Respondents in this study were children with cancer who were undergoing chemotherapy in Chronic Ward Pediatric Inpatient RSUP Dr. M. Djamil Padang. The strategy used in determining the sample was consecutive sampling amounted to 132 people. Data were collected through questionnaires that Oral Mucositis Daily Questionnaire (OMDQ) and Oral Mucositis-specific Quality of Life (OMQoL). The results showed an average of 6.55 years old respondents, the majority of the male sex, and had been diagnosed with acute lymphocytic leukemia. 40\% Respondents had experienced severe oral mucositis (a score of 2, 3, and 4) and have mild to severe limited activity primarily eating, drinking and swallowing. The average total score of the quality of life specific-oral mucositis was 58.61. Subscale diet and swallowing occupy the lowest scoring average and below the total score were 55.00 and 55.75. There were no significant differences quality of life specific-oral mucositis between mild and severe mисоsitis ( $p>0.05$ ). It is expected the professional nurse can identify conditions early oral mucous membrane of cancer patients and evaluate the implementation of oral mucositis intervention through-specific quality of life assessment of oral mucositis.
\end{abstract}

Keywords: child, cancer, chemotherapy, quality of life of specific, oral mucositis

\begin{abstract}
Abstrak
Salah satu efek samping yang umumnya terjadi selama kemoterapi adalah mukositis oral. Gangguan akibat mukositis oral ini seringkali berdampak terhadap psikologis dan penurunan kualitas hidup anak. Oleh karena itu penting untuk mengetahui hubungan mukositis oral pada pasien kanker yang menjalani kemoterapi dan kualitas hidup terkait mukositis oral. Penelitian ini merupakan penelitian deskriptif analitik dengan pendekatan cross sectional. Responden pada penelitian ini adalah anak yang mengidap kanker yang menjalani kemoterapi di Ruang Rawat Kronis IRNA Anak-Kebidanan RSUP Dr. M. Djamil Padang. Strategi yang digunakan dalam menentukan sampel adalah consecutive sampling berjumlah 132 orang. Data dikumpulkan melalui penyebaran kuesioner yaitu Oral Mucositis Daily Questionnaire (OMDQ) dan Oral Mucositis-specific Quality of Life (OMQoL). Hasil menunjukkan rata-rata responden berusia 6,55 tahun, mayoritas berjenis kelamin laki-laki dan didiagnosis mengalami leukemia limfositik akut. Kurang dari sebagian responden mengalami mukositis oral berat (skor 2, 3, dan 4) dan mengalami keterbatasan aktivitas derajat ringan hingga berat terutama makan, minum, dan menelan. Rata-rata skor total kualitas hidup spesifik-mukositis oral 58,61. Subskala diet dan menelan menempati rata-rata skor terendah dan di bawah skor total yaitu 55,00 dan 55,75. Tidak terdapat perbedaan yang signifikan kualitas hidup spesifik-mukositis oral antara mukositis ringan dan berat $(p>0,05)$. Dengan demikian diharapkan perawat professional dapat mengidentifikasi secara dini kondisi membrane mukosa oral pasien kanker dan mengevaluasi pelaksanaan intervensi mukositis oral melalui penilaian kualitas hidup spesifik-mukositis oral.
\end{abstract}

Kata kunci: anak, kanker, kemoterapi, kualitas hidup spesifik, mukositis oral 


\section{PENDAHULUAN}

Kanker merupakan penyebab utama kematian di seluruh dunia yaitu sekitar 7,6 juta kematian (13\%) pada tahun 2008 (WHO, 2013). Pada tahun 2008 diperkirakan 1,13 juta kematian terjadi akibat kanker di Wilayah Asia Tenggara (ASEAN), dan kematian akibat kanker diproyeksikan akan terus meningkat. Asia Tenggara diperkirakan memiliki 1,65 juta kasus kanker baru setiap tahun (WHO, 2013). Di Indonesia setiap tahunnya terdapat 11.000 kasus kanker pada anak (Kementerian Kesehatan Republik Indonesia, 2013).

$$
\text { Litzelman (2011) menyatakan }
$$

bahwa sejak peningkatan pengobatan kanker telah meningkatkan angka keberhasilan hidup. Di samping kemajuan dalam terapi kanker, kemoterapi terus dikaitkan dengan efek samping klinis yang sering membatasi intensitas pengobatan serta menyebabkan morbiditas yang cukup besar (Manji et al., 2012). Mukositis oral adalah inflamasi akut dan komplikasi ulseratif oral yang umumnya terjadi selama kemoterapi (Cheng et al., 2007). Anakanak dengan keganasan hematologi menerima terapi yang lebih intensif seperti leukemia mieloid akut (LMA), leukemia limfoblastik akut (LLA), dan limfoma, serta mereka yang menjalani transplantasi sel induk (SCT), berada pada risiko tinggi untuk mengembangkan mukositis (Cheng et al., 2008; Cheuk, 2008; Druley, 2009; Figliolia, 2008). Lesi dapat parah, menyebabkan rasa sakit yang signifikan, kesulitan berbicara, disfagia, hilangnya sensasi rasa, perubahan dalam status gizi, dan risiko infeksi (Allen et al., 2010; Gibson, 2010). Gangguan ini telah terbukti mempengaruhi banyak pasien sepanjang perjalanan mukositis oral, dan dapat menyebabkan tekanan psikologis yang mendalam dan penurunan kualitas hidup pasien dan status fungsional (Cheng, Lee, Li, Yuen, \& Epstein, 2012).

Telah dilakukan studi pendahuluan di Ruang Rawat Kronis Instalasi Rawat
Inap (IRNA) Rumah Sakit Umum Pusat (RSUP) Dr. M. Djamil Padang pada tanggal 5 Februari 2016. Berdasarkan laporan ruangan kronis (2015) diperoleh bahwa terjadi peningkatan kasus kanker pada anak setiap bulannya, dimana pada bulan Oktober diperoleh data anak yang mengalami kanker berjumlah 54 orang, bulan November 29 orang, pada bulan Desember 59 orang, dan bulan Januari 2016 diperoleh jumlah kasus kanker sebanyak 53 orang.

Hasil wawancara dengan 5 orang tua anak penderita kanker yang pernah menjalani kemoterapi 3 orang tua di antaranya mengatakan bahwa anaknya mengalami mulut kering dan bibir pecahpecah, 1 orang tua mengatakan gusi anak berdarah dan 1 orang tua mengatakan anaknya sering sariawan. Salah satu toksisitas kemoterapi adalah pada sistem gastrointestinal dimana $80 \%$ merupakan kejadian disfungsi rongga mulut yakni berupa mukositis (Potter \& Perry, 2006). Disfungsi ini akan berdampak pada kualitas hidup anak jika tidak diatasi. Sebagaimana penelitian Cheng et al. (2010) melaporkan bahwa seluruh pasien dengan mukositis oral mengalami penurunan pada skor subskala kualitas hidup spesifik-mukositis oral sekurangnya 10 angka dari baseline.

Berdasarkan paparan di atas, maka diperlukan penelitian tentang bagaimanakah hubungan mukositis oral pada pasien kanker yang menjalani kemoterapi dan kualitas hidupnya di Ruang Rawat Inap RSUP Dr. M. Djamil Padang.

\section{METODE}

Penelitian ini merupakan penelitian kuantitatif, menggunakan desain deskriptif analitik dengan pendekatan cross sectional. Penelitian ini telah dilakukan di Ruang Rawat Inap Anak-Kebidanan RSUP Dr. M. Djamil Padang dari bulan Maret November 2016. Populasi pada penelitian ini adalah seluruh anak yang menderita kanker yang menjalani kemoterapi yang dirawat di RSUP Dr. M. Djamil Padang. 
Jumlah pasien kanker di Ruang Rawat Kronis RSUP Dr. M. Djamil Padang 4 bulan terakhir (Oktober 2015 Januari 2016) adalah 195 orang. Jumlah sampel yang digunakan dalam penelitian ini dihitung menggunakan Raosoft software dengan tingkat kesalahan $5 \%$ dan tingkat kepercayaan 95\%, maka diperoleh 132 sampel. Sampel penelitian dipilih dari populasi secara consecutive sampling dengan kriteria 1) anak berusia 1-18 tahun, 2) anak mengalami mukositis, dan 3) anak kooperatif. Kriteria eksklusi pada penelitian ini adalah anak berada dalam kondisi sakit berat dan mengalami gangguan kognitif sehingga tidak dapat menjawab kuesioner dengan baik. Instrumen yang digunakan pada penelitian ini adalah kuisioner Oral Mucositis Daily Questionnaire (OMDQ) dan Oral Mucositis-specific Quality of Life Measure (OMQoL).

Peneliti telah memperoleh lolos kaji etik penelitian di Komite Etik Penelitian Kesehatan Fakultas Kedokteran Universitas Andalas. Lebih lanjut analisis data pada penelitian ini menggunakan analisis univariat dan bivariat. Analisis univariat digunakan untuk mengetahui frekuensi dan proporsi variabel katagorik serta mean, standar deviasi, minimum dan maksimum variabel numerik. Variabel yang akan dijelaskan melalui analisis univariat adalah karakteristik responden, katagori mukositis oral, serta total skor dan subskala kualitas hidup spesifik-mukositis oral.

Analisis bivariat dilakukan untuk mengetahui hubungan dua variabel serta membuktikan hipotesis penelitian. Sebelumnya peneliti melakukan uji normalitas data menggunakan ShapiroWilk dan diperoleh nilai $\mathrm{p}>0,05$ berarti data terdistribusi normal. Dengan demikian, uji statistik dapat dilanjutkan dengan uji parametrik yaitu independent $t$ test. Selanjutnya peneliti melakukan tes levene untuk mengetahui homogenitas varian, dimana varian homogen jika nilai $\mathrm{p}$ $>0,05$, sehingga nilai $\mathrm{p}$ yang digunakan pada uji $\mathrm{t}$ adalah equal variances assumed.

\section{HASIL}

Pengumpulan data penelitian telah dilaksanakan selama 2 bulan dan jumlah responden yang diperoleh sebanyak 20 orang. Karakteristik responden dapat dilihat pada tabel 1

Tabel 1. Potret karakteristik responden berdasarkan usia, jenis kelamin, diagnosis medis, fase kemoterapi, dan data laboratorium

\begin{tabular}{lccc}
$\begin{array}{l}\text { Karakteristik } \\
\text { responden }\end{array}$ & f $(\%)$ & $\begin{array}{c}\text { Mean } \pm \\
\text { SD }\end{array}$ & $\begin{array}{c}\text { Min- } \\
\text { Maks }\end{array}$ \\
\hline $\begin{array}{l}\text { Usia } \\
\text { a. Balita }(<5)\end{array}$ & $5(25)$ & $6,55 \pm$ & $3-14,75$ \\
b. Usia sekolah & $12(60)$ & & \\
$\quad(\geq 5-12)$ & & & \\
c. Remaja $(\geq 12-$ & $3(15)$ & & \\
$\quad$ 18) & & \\
\hline
\end{tabular}

Jenis kelamin

a. Laki-laki

$13(65)$

b. Perempuan

$7(35)$

Diagnosis medis

a. Leukemia 19 (95)

limfositik akut

b. Retinoblastoma 1 (5)

Fase kemoterapi*

a. Induksi 7 (35)

b. Konsolidasi $4(20)$

c. Profilaksis SSP $3(15)$

\begin{tabular}{|c|c|c|c|}
\hline \multicolumn{4}{|l|}{ Data } \\
\hline \multicolumn{4}{|l|}{ laboratorium* } \\
\hline $\begin{array}{l}\text { a. Netrofil } \\
\text { segmen }\end{array}$ & & $\begin{array}{c}30,5 \pm \\
24,35\end{array}$ & $2-61$ \\
\hline - Rendah & $4(20)$ & & \\
\hline - Normal & $2(10)$ & & \\
\hline - Tinggi & $0(0)$ & & \\
\hline b. Netrofil batang & & $4,67 \pm$ & $0-14$ \\
\hline - Rendah & $2(10)$ & 5,65 & \\
\hline - Normal & $2(10)$ & & \\
\hline - Tinggi & $2(10)$ & & \\
\hline c. Albumin darah & & $4,1 \pm$ & $3,4-4,6$ \\
\hline - Rendah & $3(15)$ & 0,46 & \\
\hline - Normal & $8(40)$ & & \\
\hline - Tinggi & $0(0)$ & & \\
\hline
\end{tabular}


NERS: Jurnal Keperawatan, Volume 13, No. 1, Maret 2017, (Hal. 50-59)

* Missing data pada fase kemoterapi 6 (30\%); netrofil segmen dan batang masing-masing 14 (70\%); dan albumin darah $9(45 \%)$

Dari tabel di atas diketahui bahwa sekitar $60 \%$ responden berada pada kategori usia sekolah dan selebihnya balita dan remaja, masing-masing sebanyak $25 \%$ dan $15 \%$. Rata-rata responden berusia 6,5 tahun, dimana usia terendah dan tertinggi adalah 3 tahun dan 14,75 tahun. Selanjutnya lebih dari $2 / 3$ responden berjenis kelamin laki-laki. Dilihat dari aspek diagnosis medis hampir seluruhnya menderita leukemia limfositik akut.

Tabel 2. Distribusi frekuensi mukositis oral dan keterbatasan aktivitas pada pasien kanker yang menjalani kemoterapi

\begin{tabular}{|c|c|c|}
\hline $\begin{array}{l}\text { Mukositis oral } \\
\text { dan gejala }\end{array}$ & Frekuensi & Prosentase \\
\hline $\begin{array}{l}\text { Mukositis oral } \\
\text { berat (skor } \geq 2-4 \text { ) }\end{array}$ & 8 & 40 \\
\hline $\begin{array}{l}\text { Mukositis oral } \\
\text { ringan (skor < 2) }\end{array}$ & 12 & 60 \\
\hline \multicolumn{3}{|l|}{ Tidur } \\
\hline $\begin{array}{r}\text { - Tidak ada } \\
\text { (skor } \leq 1)\end{array}$ & 19 & 95 \\
\hline $\begin{array}{l}\text { - Ringan } \\
\quad(\text { skor = 2) }\end{array}$ & 1 & 5 \\
\hline 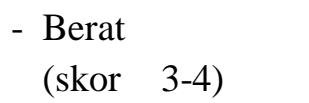 & 0 & 0 \\
\hline \multicolumn{3}{|l|}{ Menelan } \\
\hline $\begin{array}{r}\text { Tidak ada } \\
\text { (skor } \leq 1)\end{array}$ & 15 & 75 \\
\hline $\begin{array}{l}\text { - Ringan } \\
\quad(\text { skor = 2) }\end{array}$ & 3 & 15 \\
\hline 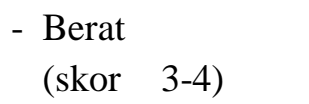 & 2 & 10 \\
\hline \multicolumn{3}{|l|}{ Minum } \\
\hline $\begin{array}{r}\text { - Tidak ada } \\
\text { (skor } \leq 1 \text { ) }\end{array}$ & 18 & 90 \\
\hline $\begin{array}{l}\text { - Ringan } \\
\quad(\text { skor }=2)\end{array}$ & 1 & 5 \\
\hline $\begin{array}{l}\text { - Berat } \\
\text { (skor } \geq 3-4 \text { ) }\end{array}$ & 1 & 5 \\
\hline Makan & & \\
\hline
\end{tabular}

\begin{tabular}{lcc}
\hline $\begin{array}{l}\text { Tidak ada } \\
(\text { skor } \leq 1)\end{array}$ & 14 & 70 \\
$-\begin{array}{l}\text { Ringan } \\
(\text { skor }=2)\end{array}$ & 1 & 5 \\
$-\begin{array}{l}\text { Berat } \\
(\text { skor } \geq 3-4)\end{array}$ & 5 & 25 \\
\hline $\begin{array}{l}\text { Berbicara } \\
- \text { Tidak ada } \\
\quad(\text { skor } \leq 1)\end{array}$ & 16 & 80 \\
$-\begin{array}{l}\text { Ringan } \\
(\text { skor }=2)\end{array}$ & 4 & 20 \\
$-\begin{array}{l}\text { Berat } \\
(\text { skor } \geq 3-4)\end{array}$ & 0 & 0 \\
\hline
\end{tabular}

Tabel di atas menunjukkan bahwa lebih dari sebagian responden mengalami mukositis oral derajat ringan. Lebih lanjut umumnya mukositis oral tidak terlalu membatasi anak dalam beraktivitas seperti tidur, menelan, minum, makan dan berbicara.

Tabel 3 memperlihatkan bahwa rata-rata skor total kualitas hidup spesifikmukositis oral adalah 58,61 dan standar deviasi 24,34 dengan skor terendah 24,08 dan tertinggi 97,50 . Rata-rata skor subskala fungsi sosial menempati nilai tertinggi yaitu 64,82 dan diikuti gejala, menelan dan diet secara berturut-turut 58,$89 ; 55,75$; dan 55,00 .

Pada tabel 4 dapat dilihat bahwa rata-rata skor total kualitas hidup spesifikmukositis oral pada mukositis oral berat 50,18 dan pada mukositis oral berat 64,24. Hasil uji statistik diperoleh tidak ada perbedaan yang signifikan rata-rata skor total kualitas hidup spesifik-mukositis oral antara mukositis ringan dan berat $(\mathrm{p}=$ 0,214). Lebih lanjut hasil uji statistik pada setiap subskala didapatkan tida ada perbedaan yang signifikan rata-rata skor subskala gejala, diet, fungsi sosial dan menelan antara mukositis oral ringan dan berat.

Tabel 3. Distribusi rata-rata skor total dan subskala kualitas hidup spesifik mukositis oral pada pasien kanker yang menjalani kemoterapi 
NERS: Jurnal Keperawatan, Volume 13, No. 1, Maret 2017, (Hal. 50-59)

\begin{tabular}{lc|c|c}
\hline $\begin{array}{l}\text { Domain } \\
\text { Kualitas hidup } \\
\text { spesifik- } \\
\text { mukositis oral }\end{array}$ & Mean & SD & $\begin{array}{c}\text { Min- } \\
\text { Mak }\end{array}$ \\
\hline Gejala & 58,89 & 26,10 & $22,22-$ \\
& & & 100 \\
Diet & 55,00 & 25,16 & $12,50-$ \\
& & & 97,50 \\
Fungsi sosial & 64,82 & 28,39 & $0,00-100$ \\
Menelan & 55,75 & 28,48 & $10,00-$ \\
& & & 100 \\
Skor total & 58,61 & 24,34 & $24,08-$ \\
& & & 97,50 \\
\hline
\end{tabular}

Tabel 4. Distribusi rata-rata skor total dan subskala kualitas hidup spesifik-mukositis oral menurut katagori mukositis oral pada pasien kanker yang menjalani kemoterapi

\begin{tabular}{|c|c|c|c|c|c|}
\hline \multirow[t]{2}{*}{$\begin{array}{l}\text { Domai } \\
\text { n }\end{array}$} & \multicolumn{2}{|c|}{$\begin{array}{l}\text { Mukositis } \\
\text { oral berat }\end{array}$} & \multicolumn{2}{|c|}{$\begin{array}{l}\text { Mukositis } \\
\text { oral ringan }\end{array}$} & \multirow{2}{*}{$\begin{array}{c}\mathbf{p} \\
\text { Valu } \\
e\end{array}$} \\
\hline & $\begin{array}{c}\text { Mea } \\
n\end{array}$ & SD & $\begin{array}{c}M e a \\
n\end{array}$ & SD & \\
\hline Skor & 50,1 & 19,9 & 64,2 & 26,1 & 0,214 \\
\hline total & 8 & 4 & 4 & 5 & \\
\hline \multirow[t]{2}{*}{ Gejala } & 54,1 & 24,4 & 62,0 & 27,7 & 0,524 \\
\hline & 7 & 4 & 4 & 4 & \\
\hline \multirow[t]{2}{*}{ Diet } & 45,3 & 16,0 & 61,4 & 28,5 & 0,124 \\
\hline & 1 & 0 & 6 & 7 & \\
\hline Fungsi & 53,1 & 26,2 & 72,6 & 28,0 & 0,136 \\
\hline sosial & 2 & 1 & 2 & 9 & \\
\hline Menela & 48,1 & 28,7 & 60,8 & 28,3 & 0,342 \\
\hline $\mathrm{n}$ & 2 & 8 & 3 & 5 & \\
\hline
\end{tabular}

\section{PEMBAHASAN}

Lebih dari sebagian responden $(60 \%)$ berada pada rentang anak usia sekolah, berjenis kelamin laki-laki $(65 \%)$ dan hampir seluruhnya (95\%) responden menderita leukemia limfositik akut (LLA). Pada anak, leukemia yang terjadi pada umumnya adalah leukemia limfositik akut
(Belson et al., 2007; Hoffbrand, 2012) dan Leukemia Mielositik Akut (LMA), dimana LLA pada anak 5 kali lebih sering terjadi dibandingkan LMA (Belson et al, 2007). Insiden LLA adalah 1/60.000 orang pertahun, dengan $75 \%$ pasien berusia kurang 15 tahun. Insiden puncaknya terjadi pada usia 3-5 tahun (Hoffbrand, 2012). Selain itu LLA lebih sering terjadi pada anak laki-laki dibandingkan anak perempuan (Smith, Gloeckler, Gurney \& Ross, 2010). Di RSUP Dr. M. Djamil Padang ditemukan bahwa LLA merupakan kasus terbanyak yang dirawat dibandingkan dengan retinoblastoma dan LMA. Berdasarkan Data Rekam Medis Pasien Instalansi Rawap Inap RSUP. Dr. M. Djamil Padang pada tahun 2015 didapatkan data sebanyak 84 anak menderita LLA, kemudian meningkat menjadi 93 anak di tahun 2016.

Insiden mukositis oral pada pasien anak dan remaja pada penelitian ini dikategorikan sebagai derajat berat (skor $\geq$ 2) sekitar $40 \%$. Hal ini sejalan dengan studi sebelumnya dimana kejadian mukositis oral $41 \%$ (Cruz, Ribeiro, Rech, Rosa, Castro, \& Brunetto, 2007; Dodd, Dibble, Miaskowski, 2001).

Salah satu efek samping kemoterapi adalah mual dan muntah, anoreksia, diare, konstipasi, masalah kulit dan kuku, kehilangan rambut, serta masalah kesehatan mulut (AMC, 2013). Masalah kesehatan mulut ini paling umum dan sering dirasakan oleh anak setelah menjalani kemoterapi. Mukositis adalah inflamasi pada mulut (Brooker, 2008). Mukositis dimulai dengan warna kemerahan dan rasa teriritasi di seluruh mulut dan tenggorokan yang dapat berlanjut menjadi memboroknya selaput lendir pipi, gusi, lidah, langit-langit dan tenggorokan (Jong, 2004). Insiden mukositis oral berkisar antara 15-40\% pada pasien penerima stomatoksik kemoterapi atau radioterapi dan 70-90\% pada penerima sumsum tulang (Cawley \& Benson, 2005). 
Mukositis akibat kemoterapi pada anak terjadi dalam beberapa fase. Fase pertama disebut fase vaskular. Pada fase ini obat kemoterapi akan merusak DNA sel mukosa normal dan mencetuskan cedera sel. Sel yang cedera akan melepaskan reactive oxygen secies (ROS). ROS merupakan agen yang berbahaya karena akan merusak jaringan. Selanjutnya jarringan yang rusak akan melapaskan agen-agen pro inflamasi seperti sitokinin, tumor necroting factor (TNF-a), interleukin 1, (IL-1), IL- $1 \mathrm{~b}$ dan Il-6. Aktivitas berbagai agen terseebut menyebabkan terjadinya fae epitelial danfase inflamasi (Dodd, 2004). Fase ini ditandai dengan pembentukan lesi dan ulserasi yang produktif. Selanjutnya lesi dan ulserasi ini akan memperburuk jika anak tidak mendapat penanganan yang tepat (Dood, 2004).

Berat ringannya mukositis tiap pasien sangat tergantung pada kondisi pasien masing-masing. Secara umum resiko terjadinya mukositis pada pasien pasca kemoterapi dipengaruhi oleh berbagai faktor. Faktor-faktor tersebut adaah jenis keganasan, umur, riwayat mukositis sebelumnya, jenis terapi yang diberikan, adanya penyakit lain yang menyertai AIDS, DM), status nutrisi serta penggunaan alkohol dan kebiasaan merokok (Cancer Care Nova Stovia [CCNS], 2004).

Menurut Dodd (2004) anak yang menderita kanker darah akan lebih seing mengalami mukositis dibandingkan anak yang menderita tumor solid. Hal tersebut terjadi karena sebagia besar agen kemoterpi untuk kanker darah memiliki tingkat mukosatosik tinggi. Selain itu siklus kemoterapinya juga lebih sering dibandingkan pasien kanker lain. Alasan lainya adalah, imunosupresi pada anak dengan kanker darah biasanya lebih berat, sehingga sistem imun lebih buruk. Hal tersebut menyebabkan anak tersebut lebih rentan terkena mukositis.

Riwayat mukositis sebelumnya juga mempengaruhi resiko mukositis berikutnya. Lesi yang ada sebelum kemoterapi akan diperburuk oleh kemoterapi. Selain itu kebiasaan dalam menjaga kebersihan mulut berkontibusi terhadap terjadinya mukositis. Anak dengan oral hygiene yang buruk lebib beresiko mendapat mukositis. Menurut Cancer Care Nova Stovia (CNNS, 2008), mukositis dapat terjadi pada 45-80 \% pasien yang menjalani kemoterapi.

Faktor lain yang mempertinggi mukositis yaitu status gizi dan status neutropenia. Adany penyakit lain seperti diabetes, AIDS, penyakit kardiopulmonal dan penyakit ginjal juga erpengaruh. Hal lain yang juga memengaruhi mukositis adalah jenis obat-obatan anti depresan, anti histamin, atau hipertensi (Nurhidayah, 2011). Anak dengan status gizi kurang atau gizi buruk biasnya akan lebih rentan mengalami mukositis (Peterson \& Carrielo, 2004).

Menurut studi United Kingdom Children's Cancer Study Group-Pediatric Oncology Nurses Forum (UKCCSGPONF) tahun 2006, sebagian besar anak yang menjalani kemoterapi akan mengalami mukositis. Pervalensi terjadinya mukositis akibat kemoterapi diperkirakan mencapai 30-75\% dalam setiap siklusnya. CCNS (2008) mengatakan bahwa angka prevalensi mukositis lebih besar lagi, yaitu sekitar 45$80 \%$. Mukositis akibat kemoterapi dapat bersifat sangat berat.

Menurut Eilers (2004), mukositis menyebabkan berbagai gangguan, diantaranya adalah gangguan fisiologis dan gangguan fungsional. Gangguan fisiologis antara lain terjadinya lesi, ulserasi, inflamasi berlebihan, nyeri dan infeksi. Lesi dan ulserasi akibat mukositis dapat menjadi predisposisi terjadinya infeksi bakteri, jamur dan virus. Hal ini mengancam kehidupan anak karena dapat menjadi infeksi yang sistemik. Sementara gangguan fungsional akibat mukositis adalah kesulitan menguyah, menelan dan berbicara. 
$\begin{array}{ccr}\text { Mukositis } & \text { akibat } & \text { kemoterapi } \\ \text { menyebabkan } & \text { terjadinya } & \text { berbagai }\end{array}$ konsekuensi. Eilers (2004) mengatakan anak dengan mukositis memerlukan penyesuaian dosis kemoterapi. Hal tersebut akan memperpanjang penatalaksanaan kanker. Konsekuensinya proses keperawatan menjadi lebih lama, sehingga akan meningkatkan biaya dan pada akhirnya akan menurunkan kualitas hidup anak.

Gangguan kesehatan mulut tersebut dapat berupa mukositis oral atau biasa disebut stomatitis, mulut kering, disfungsi kelenjer saliva, perubahan sensasri rasa dan nyeri. Gangguangangguan tersebut dapat menyebabkan komplikasi sekunder seperti kesulitan makan dan ketidakseimbangan nutrisi dan pada akhirnya akan menyebabkan penurunan kualitas hidup anak penderita kanker. Mukositis merupakan efek samping yang sering terjadi. Pergantian sel mukosa lama dengan sel mukosa baru yang cepat menyebabkan area ini sangat rentan mengalami perubahan akibat agen kemoterapi.

Menurut Dodd, et al (2004) dan Cancer Care Nova Stovia (2008) jenis obat kemoterapi berpengaruh terhadap terjadinya mukositis. Hal tersebut berkaitan dengan tingkat potensi untuk menimbulkan mukositis atau biasa disebut potensi mukositik atau mukosatoksik. Riwayat mukositis sebelumnya juga mempengaruhi risiko mukositis berikutnya (Avitscher, Cooksley \& Elting, 2004). Lesi yang ada sebelum kemoterapi akan diperburuk oleh kemoterapi. Selain itu kebiasaan dalam menjaga kebersihan mulut berkontribusi terhadap terjadinya mukositis. Efek obat kemoterapi dapat menyebabkan ulkus pada mulut (mukositis) dan kerongkongan. Kemoterapi dapat membuat sekitar mulut menjadi kering, iritasi, dan dapat menyebabkan perdarahan.ulkus pada mulut tidak hanya menyebabkan nyeri tetapi juga menyebabkan infeksi oleh mikroorganisme yang hidup pada area mulut. Ketika terjadi infeksi maka dapat menjadi perlawanan yang berat selama kemoterapi dan dapat menimbulkan masalah yang serius (AMC, 2013). Jenis dan dosis yang diterima anak selama kemoterapi itu akan mempengaruhi derajat mukosistis anak. Menurut Dodd, 2004) jenis obat, dosis, intensitas, durasi dan frekuensi pemberian obat kemoterapi akan meningkatkan terjadinya mukosistis. Vinkristin merupakan obat kemoterapi yang memilki derajat sedang terjadinya mukositis, sedangkan obat cytarabin merupakan obat kemoterapi yang sangat tinggi terjadinya mukositis.

OMQoL dikembangkan untuk mengukur berbagai aspek penting dari kualitas hidup yang menilai dimensi status kesehatan terutama mukositis oral. Dalam studi ini, peneliti mengidentifikasi bahwa responden pada kelompok mukositis oral berat memiliki kualitas hidup yang lebih rendah dibandingkan dengan kelompok mukositis oral ringan.

\section{KESIMPULAN DAN SARAN}

Berdasarkan uraian pada hasil penelitian dan pembahasan, maka dapat disimpulkan bahwa rata-rata responden berusia 6,55 tahun, mayoritas berjenis kelamin laki-laki dan didiagnosis mengalami leukemia limfositik akut. Kurang dari sebagian responden mengalami mukositis oral berat (skor 2, 3, dan 4) dan mengalami keterbatasan aktivitas derajat ringan hingga berat terutama makan, minum, dan menelan.

Selanjutnya rata-rata skor total kualitas hidup spesifik-mukositis oral masih tergolong rendah yaitu 58,61. Bahkan subskala diet dan menelan menempati rata-rata skor terendah dan berada di bawah skor total yaitu 55,00 dan 55,75 . Oleh karena itu diharapkan perawat professional dapat mengidentifikasi secara dini keutuhan membrane mukosa oral pasien yang memperoleh kemoterapi secara berkala sehingga dapat memberikan 
upaya pencegahan dan perawatan yang efektif. Selain itu kualitas hidup spesifikmukositis oral dapat menjadi acuan dalam mengevaluasi intervensi mukositis oral. Tidak terdapatnya perbedaan yang signifikan kualitas hidup spesifikmukositis oral antara mukositis ringan dan berat kemungkinan jumlah sampel yang masih sedikit sehingga diharapkan di masa datang dapat melanjutkan penelitian ini dengan memperbesar jumlah sampel dan menggunakan kuesioner yang berbeda yang telah melewati uji validitas dan reliabilitas.

\section{DAFTAR PUSTAKA}

Alatas, H., Karyomanggolo, W. T., Musa, D. A., Boediarso, A., Oesman, I. N., \& Idris, N. S. (2011). Desain penelitian. In Sastroasmoro, S., \& Ismael, S. Dasar-dasar metodologi penelitian klinis (pp.104-128). Jakarta: Sagung Seto.

Bredow, T. S., \& Peterson, S. J. (2004). Health-related quality of life. In Peterson, S. J., \& Bredow, T. S. Middle range theories: Application to nursing research (pp. 274-287). Philadelphia: Lippincott Williams \& Wilkins.

Chaimberg, K.H., \& Cravero, J.P. (2004). Mucositis and airway obstruction in a pediatric patient. Anesthesia and Analgesia, 99, 59-61. doi: 10.1213/01.ANE.0000121309.01069.0 A

Cheng, K. K. F., Lee, V., Li, C. H., Yuen, H. L., \& Epstein, J. B. (2012). Oral mucositis in pediatric and adolescent patients undergoing chemotherapy: The impact of symptoms on quality of life. Supportive Care in Cancer, 20(10), 2335-2342. http://doi.org/10.1007/s00520-0111343-1

Cheng, K. K. F., Leung, S. F., Liang, R. H. S., Tai, J. W. M., Yeung, R. M. W., \& Thompson, D. R. (2010). Oropharyngeal mucositis-spesific quality-of-life measure in patients with cancer therapy. Hong Kong Med J, 16(3), 42-46

Cheng, K. K., Goggins, W. B., Lee V. W., Thompson, D. R. (2008). Risk factors for oral mucositis in children undergoing chemotherapy: a matched case-control study. Oral Oncol, 44:1019-1025

Cheng, K. K. F., Leung, S. F., Thompson, D. R., Tai, J. W. M., Liang, R. H. S., Kan, A. S. T., ... Yeung, R. M. W. (2007). New measure of health-related quality of life for patients with oropharyngeal mucositis: development and preliminary psychometric evaluation. Cancer, 109(12), 2590-9. http://doi.org/10.1002/cncr.22730

Cheng, K. K., Chang, A. M., \& Yuen, M. P. (2004). Prevention of oral mucositis in paediatric patients treated with chemotherapy: A randomised crossover trial comparing two protocols of oral care. European Journal of Cancer, 40, 1208-1216. doi: 10.1016/j.ejca.2003.10.023

Cheng, K.K. (2004). Children's acceptance and tolerance of chlorhexidine and benzydamine oral rinses in the treatment of chemotherapy-induced oropharyngeal mucositis. European Journal of Oncology Nursing, 8, 341349.

Cheng, K. K., Molassiotis, A., \& Chang, A. M. (2002). An oral care protocol intervention to prevent chemotherapyinduced oral mucositis in paediatric cancer patients: A pilot study. Euro- 
NERS: Jurnal Keperawatan, Volume 13, No. 1, Maret 2017, (Hal. 50-59)

pean Journal of Oncology Nursing, 6(2), 66-73. doi: 10.1054/ejon.2001.0161

Cheuk, D. K., Lee, T.L., Chiang, A.K., Ha, S. Y., Chan, G. C. (2008). Autologous hematopoietic stem cell transplantation for high-risk brain tumors in children. J Neuro-Oncol, 86:337-347

Crawford, S.W., \& Petersen, F.B. (1992). Long-term survival from respiratory failure after marrow transplantation for malignancy. American Review of Respiratory Disease, 145, 510-514.

Drew, B., Peters, C., \& Rimell, F. (2000). Upper airway complications in children after bone marrow transplantation. Laryngoscope, 110 , 1446-1451. doi: 10.1097/00005537200009000-00006

Druley, T. E., Hayashi, R., Mansur, D. B., Zhang, Q. J., Barnes, Y., Trinkaus, K., Witty, S., Thomas, T., Klein, E. E., DiPersio, J. F., Adkins, D., Shenoy, S. (2009) Early outcomes after allogeneic hematopoietic SCT in pediatric patients with hematologic malignancies following single fraction TBI. Bone Marrow Transpl, 43:307314

Elting, L., Cooksley, C., Chambers, M., Cantor, S., Manzullo, E., \& Rubenstein, E. (2003). The burdens of cancer therapy: Clinical and economic outcomes of chemotherapy-induced mucositis. Cancer, 98, 1531-1539. doi: 10.1002/cncr.11671

Manji, A., Tomlinson, D., Ethier, M. C., Gassas, A., Maloney, A. M., \& Sung, L. (2012). Psychometric properties of the Oral Mucositis Daily Questionnaire for child self-report and importance of mucositis in children treated with chemotherapy. Supportive
Care in Cancer, 20(6), 1251-1258. http://doi.org/10.1007/s00520-0111211-z

Fadda, G., Campus, G., \& Luglie, P. (2006). Risk factors for oral mucositis in paediatric oncology patients receiving alkylant chemotherapy. BioMed Central Oral Health, 6(13), $1-8$

.Figliolia, S. L., Oliveira, D. T., Mello de Andrea, M. L. (2008). Oral mucositis in acute lymphoblastic leukaemia: analysis of 169 paediatric patients. Oral Dis, 14:761-766

Gibson, F., Auld, E. M., Bryan, G., Coulson, S., Craig, J. V., Glenny, A. M. (2010). A systematic review of oral assessment instruments: what can we recommend to practitioners in children's and young people's cancer care? Cancer Nurs, 33:E1-E19

Gippsland Oncology Nurses Group. (2007). Cancer related mucositis management: GONG cancer care guidelines. Retrieved from http://www.gha.net.au/Uploadlibrary/3 93586894mucositis_management_gui delines0606.pdf

Hockenberry, M.J., Hooke, M.C., Gregurich, M., \& McCarthy, K. (2009). Carnitine plasma levels and fatigue in children/adolescents receiving cisplatin ifosfamide or doxorubicin. Journal of Pediatric Hematology/Oncology, 31, 664-669. doi: 10.1097/MPH.0b013e3181b259a7

Kowanko, I., Hodgkinson, B., Long, L., \& Evans, D. (1998). Prevention and treatment of oral mucositis in cancer patients. Best Practice, 2(3), 1-6.

Litzelman, K., Catrine, K., Gangnon, R., \& Witt, W. P. (2011). Quality of life among parents of children with cancer 
NERS: Jurnal Keperawatan, Volume 13, No. 1, Maret 2017, (Hal. 50-59)

or brain tumors: The impact of child characteristics and parental psychosocial factors. Quality of Life Research, 20(8), 1261-9. doi: http://dx.doi.org/10.1007/s11136-0119854-2

Logan, R.M., Stringer, A.M., Bowen, J.M., Yeoh, A.S.J., Gibson, R.J., Sonis, S.T., \& Keefe, D.M. (2007). Complications of treatment. Cancer Treatment Reviews, 33, 448-460.

National Cancer Institute Cancer Therapy Evaluation Program. (1999). Common Terminology Criteria [v.2.0]. Retrieved from http://ctep.cancer.gov/protocoldevelop ment/electronic_applications/docs/ctcv20_4-30-992.pdf

Novik, A., Salek, S., \& Ionova, T. (2012). Guidelines patient-reported outcomes in hematology. Retrieved from www.ehaweb.org

Sonis, S.T., Oster, G., Fuchs, H., Bellm, L., Bradford, W.Z., Edelsberg, J., . . . Horowitz, M. (2001). Oral mucositis and the clinical and economic outcomes of hematopoietic stem-cell transplantation. Journal of Clinical Oncology, 19, 2201-2205.

Sung, L., Klaassen, R. J., Dix, D., Pritchard, S., Yanofsky, R., Dzolganovski, B., . . Klassen, A. (2009). Identification of paediatric cancer patients with poor quality of life. The British Journal of Cancer, 100(1), 82-8. doi: http://dx.doi.org/10.1038/sj.bjc.66048 $\underline{26}$

Warwick, A.B., Mertens, A.C., Shu, X.O., Ramsay, N.K., \& Neglia, J.P. (1998).

Outcomes following mechanical ventilation in children undergoing bone marrow transplantation. Bone Marrow
Transplantation, 22, 787-794. doi: 10.1038/sj.bmt.17014 